\title{
Sedimentation Properties of Ribonucleic Acid from Rhodopseudomonas spheroides
}

\author{
By LYDIA BORDA, M. H. GREEN AND M. D. KAMEN \\ Departments of Chemistry and Biology, University of California \\ at San Diego, La Jolla, California 92037, U.S.A.
}

(Accepted for publication 18 February 1969)

SUMMARY

Phenol-purified RNA was prepared from Rhodopseudomonas spheroides and characterized by sucrose-gradient centrifugation. The patterns obtained indicate that $R$. spheroides possesses a ribosomal RNA complement similar to that of Escherichia coli. This is contrary to previous claims that the $23 \mathrm{~S}$ component is missing. This species of ribosomal RNA was demonstrated to be more labile than the corresponding component in $E$. coli and variations in yields produced by changes in extraction procedures are described.

\section{INTRODUCTION}

Although sedimentation profiles of ribosomes obtained from many species of bacteria invariably exhibit $50 \mathrm{~S}$ and $30 \mathrm{~S}$ subunits, which yield respectively $23 \mathrm{~S}$ and I6S RNA molecules (Osawa, I968), it has been reported (Lessie, I965) that the facultative photoheterotroph, Rhodopseudomonas spheroides, does not contain the 23RNA species, which implies that this bacterium is unique in that it can build all its ribosomes from the I6S species alone. However, some data indicating that $R$. spheroides does in fact contain the usual ribosomal subunits have appeared (Lessie, 1965; Friedman, Pollara \& Gray, I966). In addition, the sedimentation profiles of Rhodospirillum rubrum and other facultative photoheterotrophs have revealed both types of RNA with sedimentation characteristics quite similar to those obtained from Escherichia coli (Lessie, I965; Yamashita \& Kamen, 1968). In the course of researches on polynucleotide metabolism in $R$. spheroides, we have had occasion to examine RNA composition in this organism, including not only the strain investigated originally but also two others-one of which is a uracil-requiring mutant-and report herewith that in all cases the $23 \mathrm{~S}$ RNA component can be isolated, but that its lability is pronounced. This fact appears to be the source of the present contradictions in previous reports.

\section{METHODS \\ Organisms}

The strains of Rhodopseudomonas spheroides used were: no. 2.4. I (originally from the collection of Professor C. B. van Niel); another culture of no. 2.4. I obtained from Dr S. Kaplan; and no. 5-I I, a uracil-requiring mutant of strain GA, obtained from Dr J. Lascelles. The Escherichia coli used was laboratory strain KI2-W3IIO. 


\section{Growth of Organisms}

Rhodopseudomonas spheroides was grown photosynthetically, from a $\mathrm{I} / \mathrm{IO}(\mathrm{V} / \mathrm{v})$ inoculum, in medicine bottles, under strong illumination, at 30 to $32^{\circ}$, in the glutamate medium of Lascelles (1959). For radioactive labelling, the medium was supplemented with $0.5 \mu \mathrm{c} / 2 \mu \mathrm{g} . / \mathrm{ml}$. of either tritiated or ${ }^{14} \mathrm{C}$-uracil. Organisms were grown mostly to about the second half of the logarithmic phase, although on occasion organisms in early stationary phase were used with no apparent effect on results. Escherichia coli was grown with forced aeration, at $37^{\circ}$, for about five generations in $\mathrm{K}$ medium (Green, 1966), supplemented with $0.5 \mu \mathrm{C}{ }^{14} \mathrm{C}$-uracil $/ 2 \mu \mathrm{g} . / \mathrm{ml}$. All organisms were harvested by centrifugation. As explained in the Results section, it was found necessary to avoid storage by freezing and to use these suspensions immediately for RNA isolation and characterization.

\section{Preparation of phenol-purified RNA from Rhodopseudomonas spheroides}

Organisms were washed once with the appropriate buffer (see Results) and resuspended, at about $\frac{1}{10}$ th of their original volume, in buffer containing Io $\mu \mathrm{g}$. DNase (Worthington DNase I, electrophoretically purified) per $\mathrm{ml}$. The suspensions were chilled on ice and passed through a pre-cooled French pressure cell at 5000 to 9000 p.s.i. They were then left at room temperature for 10 to $15 \mathrm{~min}$. for degradation of the DNA. Sodium dodecylsulphate (SDS) was added to a final concentration of 0.5 to $\mathrm{I} \%$ and the mixture extracted three times with freshly distilled phenol equilibrated with the buffer used in extraction. The aqueous phase of the last extraction was precipitated with twice its volume of ethanol, in ice, for about one half hour. When the extinction was to be measured, the precipitates were washed twice with ether to remove traces of phenol, then dried with air. The precipitates were dissolved in small volumes of SSC (0.15 M-NaCl, 0.015 M-Na citrate).

\section{Preparation of phenol-purified RNA from Escherichia coli}

The bacteria were washed once with $5 \times 10^{-3} \mathrm{M}$-tris- $\mathrm{Cl}, \mathrm{pH} 7 \cdot 3$, containing $10^{-2} \mathrm{M}-$ $\mathrm{MgSO}_{4}$. They were resuspended in the same buffer at $\frac{1}{25}$ th of their original volume, and lysozyme was added to a concentration of $100 \mu \mathrm{g} . / \mathrm{ml}$. The bacteria were then frozen and thawed three times, over a period of $40 \mathrm{hr}$. After the last thawing DNase was added to a final concentration of about $20 \mu \mathrm{g} . / \mathrm{ml}$., and degradation allowed to proceed at room temperature for $15 \mathrm{~min}$. The preparation was made I \% in SDS and stirred well. It was then extracted three times with freshly distilled phenol equilibrated with the above buffer. The aqueous phase from the last extraction was precipitated with twice its volume of ethanol. After centrifugation, the precipitates were dried with air and dissolved in a small volume of SSC.

\section{Sucrose gradient centrifugation}

Linear, $27 \mathrm{ml}$. gradients of 5 to $20 \% \mathrm{w} / \mathrm{v}$ sucrose in $0.0 \mathrm{I} \mathrm{M}$-tris- $\mathrm{Cl}+0 . \mathrm{I} \mathrm{M}-\mathrm{NaCl}$, $\mathrm{pH} 7 \cdot 5$, were prepared with the aid of an apparatus similar to that of Britten \& Roberts (1960). The gradients were left to equilibrate in the cold $\left(4^{\circ}\right)$ for at least one half hour and up to $24 \mathrm{hr}$. A small sample $(0.05$ to $0.2 \mathrm{ml}$.) of the phenol-purified RNA preparations was layered on top of the gradient and centrifugation performed in 
a Model L or a Model L-2 Beckman ultracentrifuge, using the SW $25 \cdot \mathrm{I}$ swinging bucket rotor $\left(24,000 \mathrm{rev} . / \mathrm{min}\right.$., I $\left.5 \mathrm{hr}, T=3^{\circ}\right)$. One $\mathrm{ml}$. fractions were collected from the tubes after puncture in the usual fashion. Radioactive samples were precipitated with cold trichloracetic acid (TCA), filtered over Schleicher and Schuell type B-6 membrane filters, and counted in a scintillation counter. Unlabelled samples were assayed by their extinction at $260 \mathrm{~m} \mu(\mathrm{nm}$.).

\section{RESULTS}

It was found that Rhodopseudomonas spheroides possessed an RNA complement similar to that of Escherichia coli, i.e. the ribosomal RNA had two components that corresponded to the $\mathrm{I} 6 \mathrm{~S}$ and $23 \mathrm{~S}$ RNAs. However, the $23 \mathrm{~S}$ RNA was labile with yields varying under different conditions of extraction.

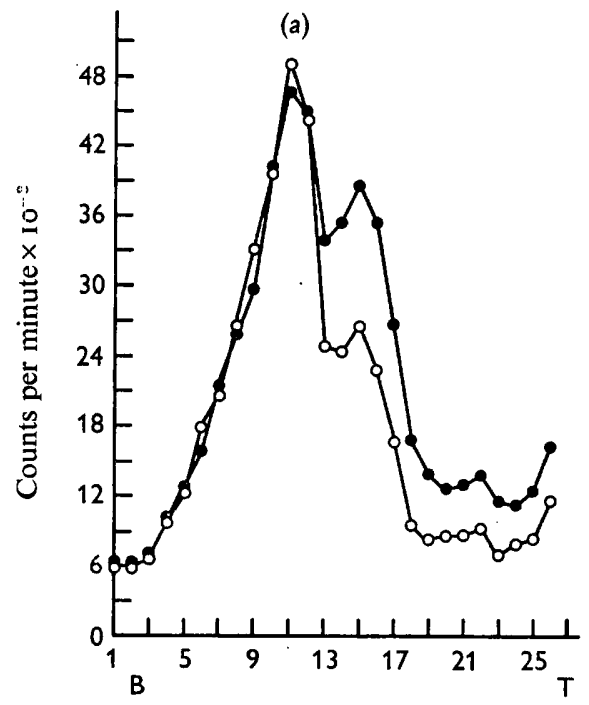

Tube number (b)

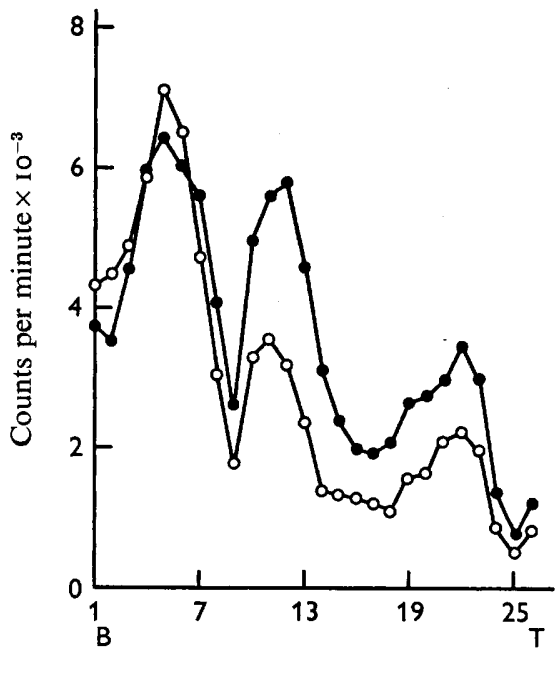

Tube number

Fig. I(a). Sucrose gradient pattern of a mixed preparation of Rhodopseudomonas spheroides and Escherichia coli RNA, in the absence of $\mathrm{Mg}^{2+}, R$. spheroides no. 2.4. I was grown on ${ }^{3} \mathrm{H}$-uracil; $E$. coli was grown on ${ }^{14} \mathrm{C}$-uracil. The two cultures were mixed; RNA was phenol purified, precipitated with alcohol and dissolved in SSC. A portion of this preparation was layered on top of a $5-20 \%(\mathrm{w} / \mathrm{v})$ sucrose gradient in $10^{-2} \mathrm{M}$-tris- $\mathrm{Cl},(\mathrm{pH} 7.5),+0.1$ $\mathrm{M}-\mathrm{NaCl}$ - - O-, ${ }^{14} \mathrm{C}$ (E. coli RNA); - - ${ }^{3} \mathrm{H}$ (R. spheroides RNA).

(b) Sucrose gradient pattern of a mixed preparation of $R$. spheroides and $E$. coli RNA in the presence of $10^{-2} \mathrm{M}-\mathrm{Mg}^{2+}$. The RNA preparation in Fig. I $a$ was dialysed against $5 \times 10^{-3} \mathrm{pHM}$-tris-Cl $(\mathrm{pH} 7 \cdot 5),+\mathrm{IO}^{-2} \mathrm{M}^{-\mathrm{MgSO}_{4}}$ and analysed as in Fig. I $a$ except that the gradient contained also $1 \mathrm{IO}^{-2} \mathrm{M}-\mathrm{Mg}^{2+}$. $-\mathrm{O}-,{ }^{14} \mathrm{C}(E$. coli $\mathrm{RNA}) ;--,-{ }^{3} \mathrm{H}(R$. spheroides RNA)

In one experiment Rhodopseudomonas spheroides was grown on ${ }^{3} \mathrm{H}$-uracil and Escherichia coli on ${ }^{14} \mathrm{C}$-uracil, as described in the Methods section. After measuring the TCA precipitable counts, the two cultures were mixed so as to contain an approximately equivalent amount of the two isotopes, and RNA was extracted from the mixed cultures by the usual procedure (see Methods); the buffer used was 0.005 M-tris- 


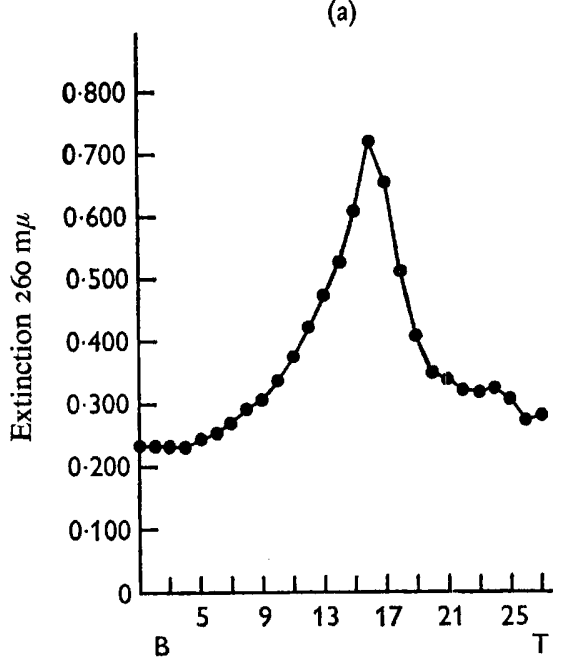

Tube number

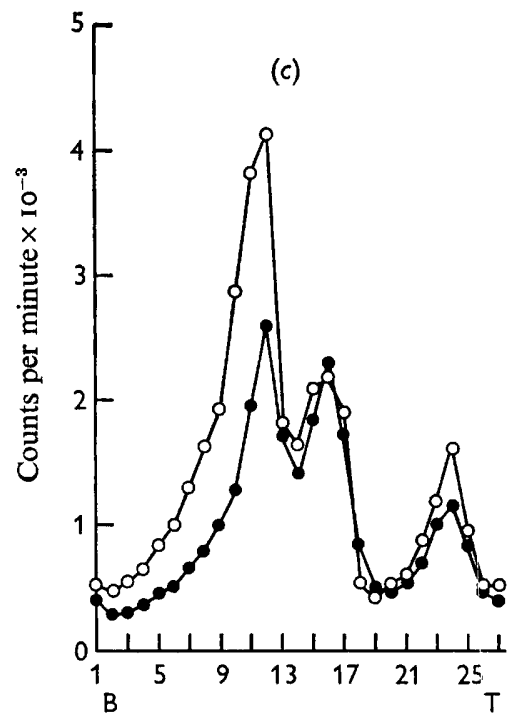

Tube number

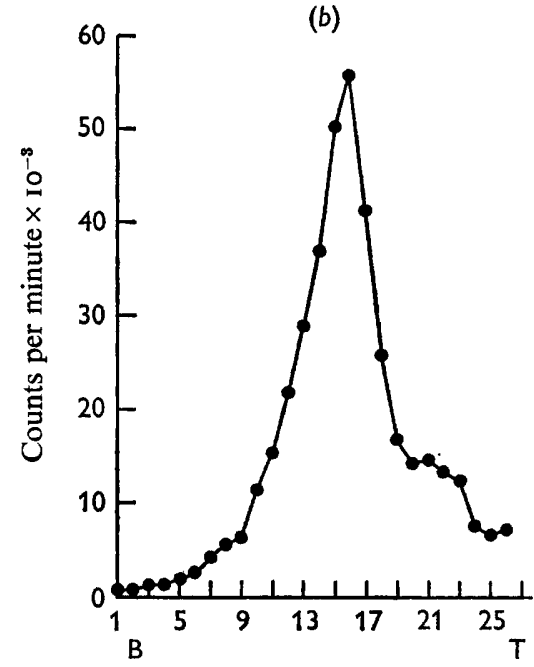

Tube number

(d)

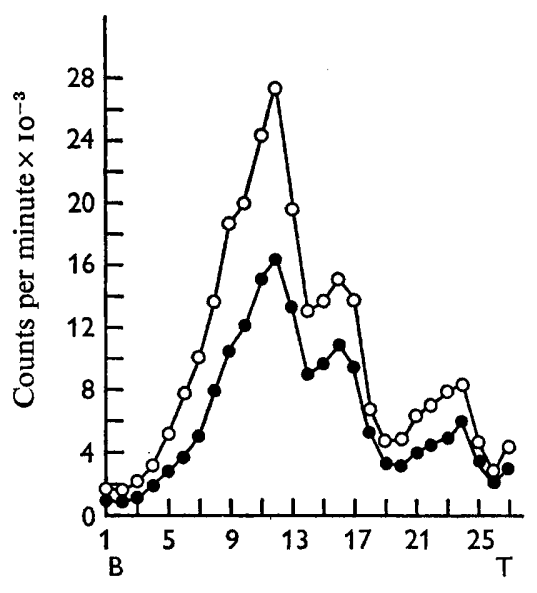

Tube number

(e)

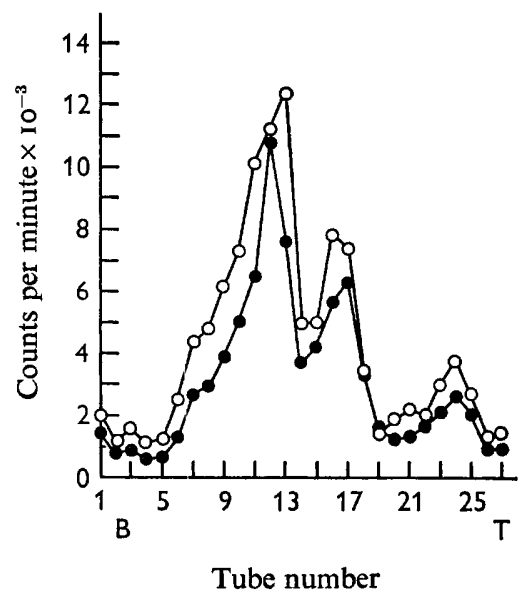

Fig. 2. For legend see opposite page. 
$\mathrm{Cl},(\mathrm{pH} \mathrm{7} 3)+0.01 \mathrm{M}^{-\mathrm{MgSO}_{4}}\left({ }^{\prime \prime} \mathrm{TM}^{\prime \prime}\right)$. Part of the final preparation (in SSC) was analysed on a sucrose gradient (Fig. I $a$ ). Another portion was dialysed against TM buffer and then analysed on a sucrose gradient containing $10^{-2} \mathrm{M}-\mathrm{MgCl}_{2}$ (Fig. I $b$ ). The resulting fractionation pattern clearly revealed RNA complements similar to those of $E$. coli, i.e. three peaks corresponding to the $4 \mathrm{~S}$, I6S and $23 \mathrm{~S}$ species. Moreover, $R$. spheroides RNA, like $E$. coli RNA, sedimented more rapidly in the presence of $\mathrm{Mg}^{2+}$, but the three components were again clearly visible. However, the ratio of 23S to I6S RNA in $E$. coli was approximately $2: \mathrm{I}$, as expected for an equal number of $50 \mathrm{~S}$ and $30 \mathrm{~S}$ ribosomes (because $23 \mathrm{~S}$ RNA has twice the molecular weight of $16 \mathrm{~S}$ RNA), while for $R$. spheroides the ratio was lower. Since all operations were carried out on the mixed cultures, it was apparent that $23 \mathrm{~S}$ RNA in $R$. spheroides was more labile.

In the course of a large number of RNA extractions from the three different cultures of Rhodopseudomonas spheroides used, the relative amounts of ${ }_{23} \mathrm{~S}$ and $\mathrm{I} 6 \mathrm{~S}$ ribosomal RNA were found to vary, ranging from no apparent $23 \mathrm{~S}$ to a ratio of $23 \mathrm{~S} / \mathrm{I} 6 \mathrm{~S}$ of $\mathrm{I} \cdot 7$ in the best preparation obtained (see Fig. $2 a-e$ ).

The phenol-purified RNA preparations degraded randomly with time when stored at $4^{\circ}$. At $-20^{\circ}$ they were more stable, but a decrease in the $23 \mathrm{~S}$ to I $6 \mathrm{~S}$ ratio was still noted. It appeared that the $23 \mathrm{~S}$ RNA was sensitive to extraction conditions. Further experiments were performed to evaluate the effects of different parameters in the extraction procedure.

(a) Effect of $\mathrm{Mg}^{2+}$ concentration. As this factor was known to affect the $23 \mathrm{~S}$ to I6S ratio in Escherichia coli (Midgley, $1965 a$ ), we tried extractions in $5 \times 10^{-3} \mathrm{M}$-tris-Cl,

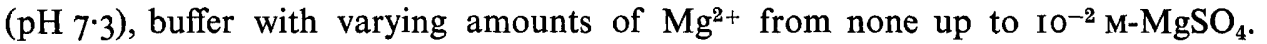
In general, slightly higher yields of $23 \mathrm{~S}$ relative to $\mathrm{I} 6 \mathrm{~S}$ were obtained in the absence of $\mathrm{Mg}^{2+}$, but the over-all yields of RNA extracted in this manner were from 2 to Io times lower than when $\mathrm{Mg}^{2+}$ was present. Therefore, when it is not essential to have intact $23 \mathrm{~S}$ RNA, as in preparations used for hybridization assays, we recommend extraction in the presence of $\mathrm{Mg}^{2+}$.

(b) Phenol. It was found essential for both Rhodopseudomonas spheroides and Escherichia coli that phenol be freshly distilled. Various methods for storage of distilled phenol were tried, such as maintenance at $4^{\circ}$ or $-10^{\circ}$, presence or absence

Fig. 2. Sucrose gradient patterns of several preparations of RNA from Rhodopseudomonas spheroides. The gradient was 5 to $20 \%(\mathrm{w} / \mathrm{v})$ sucrose in $\mathrm{I}^{-2} \mathrm{M}$-tris- $\mathrm{Cl},(\mathrm{pH} 7 \cdot 5)+0 \cdot \mathrm{I} \mathrm{M}-\mathrm{NaCl}$. ${ }^{14} \mathrm{C}$ labelled RNA from $E$. coli was prepared separately and was used in some of the experiments as a marker.

(a) $R$. spheroides suspension used for RNA extraction had been stored in frozen state for several months.

(b) R. spheroides suspension used was kept suspended in $0.005 \mathrm{M}$-tris- $\mathrm{Cl},(\mathrm{pH} 7 \cdot 5)+1 \mathrm{O}^{-2} \mathrm{M}-$ $\mathrm{MgSO}_{4}$, at $4^{\circ}$, for $48 \mathrm{hr}$, before breaking it and extracting the RNA.

(c) RNA from $R$. spheroides 5-II, a uracil auxotroph obtained from Dr J. Lascelles. $-{ }^{-},{ }^{14} \mathrm{C}$ ( $E$. coli RNA); - - - ${ }^{3} \mathrm{H}$ ( $R$. spheroides RNA).

(d) RNA from $R$. spheroides no. 2.4. I obtained from Dr S. Kaplan. $-\mathrm{O}-{ }^{14} \mathrm{C}(E$. coli RNA); - - ${ }^{3} \mathrm{H}$ ( $R$. spheroides $\left.\mathrm{RNA}\right)$.

(e) One of the better RNA preparations obtained from the culture of Rhodopseudomonas spheroides no. 2.4. I that was used in most of this work. $-\mathrm{O}-,{ }^{14} \mathrm{C}$ (E. coli RNA); $-{ }^{3} \mathrm{H}$ ( $R$. spheroides RNA). 
of buffer, use of nitrogen and avoidance of light. None of these practices, however, singly or together, proved to be entirely reliable, and it was concluded that phenol should be freshly distilled and used within $24 \mathrm{hr}$.

(c) Previous history of cells. Little or no $23 \mathrm{~S}$ RNA was obtained from organisms that had been frozen for several months or kept for $48 \mathrm{hr}$ at $4^{\circ}$ in the extraction buffer. In this context it is to be noted that previous negative findings involved the use of frozen organisms (Lessie, 1965).

\section{DISCUSSION}

The characteristics of Rhodopseudomonas spheroides RNA may be correlated with those of Escherichia coli ribosomal RNA. Thus, studies of the latter have shown that, when extraction conditions are not optimal (Midgley, 1965a), or upon mild alkaline treatment (Midgley, 1965b), 23S RNA can be degraded, producing predominantly RNA of the I6S class. However, E. coli $23 \mathrm{~S}$ RNA exhibits only one $3^{\prime}$-terminal residue (Midgley, 1965c) and one 5'-terminal residue (Takanami, 1967) per molecule, indicating it is not a simple dimer of the I6S RNA. Our extractions of RNA from mixed cultures of $R$. spheroides and $E$. coli produce $E$. coli ribosomal RNA in almost the theoretical ratio, whereas the $23 \mathrm{~S}$ component from $R$. spheroides is obtained in relatively low yield. This observation might argue for some unusually fragile linkage(s) in the $R$. spheroides $23 \mathrm{~S}$ RNA which may be particularly susceptible to nuclease attack. Observations on the liberation of various non-covalently bound enzymes from mitochondrial membranes by freezing and thawing (Egger \& Rapoport, I963) support our suggestion that previous negative findings (Lessie, 1965) were due at least in part to the use of frozen cells. One may note also that in these negative experiments even the E. coli $\mathrm{RNA}$ preparation exhibited a ratio of $23 \mathrm{~S}$ to $\mathrm{I} 6 \mathrm{~S}$ of I $\mathrm{I}$ instead of the theoretical $2: \mathrm{I}$. We may conclude that the composition of ribosomal RNA in $R$. spheroides is much like that of $E$. coli and other bacteria and requires no supposition of uniqueness, at least in sedimentation behaviour.

Support for these researches has come in part from grants-in-aid of the United States Public Health Service (HD-oI 262, GM-I 43 I 8), the National Science Foundation (GB-7033x) and the C. F. Kettering Research Foundation. The senior author holds a USPHS predoctoral fellowship (no. 5-FoI-GM 32110).

\section{REFERENCES}

BRITTEN, R. J. \& Roberts, R. B. (1960). High resolution gradient sedimentation analysis. Science, $N . Y$. I31, 32.

EGGER, E. \& RAPOPORT, S. (1963). Role of non-covalent bonds for the holding, activation and release of mitochondrial enzymes. Nature, Lond. 200, 240.

Friedman, D. I., Pollara, B. \& Gray, E. D. (1966). Structural studies of the ribosomes of Rhodopseudomonas spheroides. J. molec. Biol. 22, 53.

GREEN, M. H. (I966). Inactivation of the prophage Lambda repressor without induction. J. molec. Biol. 16, I 34 .

LASCELlES, J. (1959). The synthesis of enzymes concerned in bacteriochlorophyll formation in growing cultures of Rhodopseudomonas spheroides. J. gen. Microbiol. 23, 487.

LESSIE, T. G. (I965). The atypical ribosomal RNA complement of Rhodopseudomonas spheroides. J. gen. Microbiol. 39, $3 \mathrm{II}$. 
MIDGLEY, J. E. M. (1965a). Effects of different extraction procedures on the molecular characteristics of bacterial ribosomal ribonucleic acid. Biochim. biophys. Acta 95, 232.

MIDGLEY, J. E. M. (1965 b). Studies on the structure of $23 \mathrm{~S}$ ribosomal ribonucleic acid from Escherichia coli. Biochim. biophys. Acta ro8, 348.

Midgley, J. E. M. (I965c). The estimation of polynucleotide chain length by a chemical method. Biochim. biophys. Acta 108, 340.

OSAWA, S. (1968). Ribosome formation and structure. A. Rev. Biochem. 37, 109.

TaKanami, M. (I967). Analysis of the 5'-terminal nucleotide sequences of ribonucleic acids. I. The 5'-termini of Escherichia coli ribosomal RNA. J. molec. Biol. 23, 135.

YAMASHITA, J. \& KAMEN, M. D. (1968). Observations on the nature of pulse-labelled RNA from photosynthetically or heterotrophically grown Rhodospirillum rubrum. Biochim. biophys. Acta I6I, 162 . 